\title{
Fusion between M2-macrophages and cancer cells results in a subpopulation of radioresistant cells with enhanced DNA-repair capacity
}

\author{
Annelie Lindström¹, Kristine Midtbö ${ }^{1}$, Lars-Gunnar Arnesson ${ }^{3}$, Stina Garvin ${ }^{2}$ and \\ Ivan Shabo ${ }^{3,4,5}$ \\ ${ }^{1}$ Division of Cell Biology, Department of Clinical and Experimental Medicine, Linköping University, SE 581 85, Linköping, Sweden \\ ${ }^{2}$ Department of Clinical Pathology, Department of Clinical and Experimental Medicine, Linköping University, SE 581 85, Linköping, \\ Sweden \\ ${ }^{3}$ Division of Surgery, Department of Clinical and Experimental Medicine, Linköping University, SE 581 85, Linköping, Sweden \\ ${ }^{4}$ Endocrine and Sarcoma Surgery Unit, Department of Molecular Medicine and Surgery, Karolinska Institutet, SE 171 77, Stockholm, \\ Sweden \\ ${ }^{5}$ Department of Breast and Endocrine Surgery, Karolinska University Hospital, SE 171 76, Stockholm, Sweden
}

Correspondence to: Ivan Shabo, email: Ivan.Shabo@ki.se

Keywords: cell fusion, M2-macrophage, radiotherapy, breast cancer, radioresistance

Received: March 06, 2017 Accepted: May 07, $2017 \quad$ Published: May 18, 2017

Copyright: Lindström et al. This is an open-access article distributed under the terms of the Creative Commons Attribution License 3.0 (CC BY 3.0), which permits unrestricted use, distribution, and reproduction in any medium, provided the original author and source are credited.

\section{ABSTRACT}

Cell fusion is a natural biological process in normal development and tissue regeneration. Fusion between cancer cells and macrophages results in hybrids that acquire genetic and phenotypic characteristics from both maternal cells. There is a growing body of in vitro and in vivo data indicating that this process also occurs in solid tumors and may play a significant role in tumor progression. However, investigations of the response of macrophage:cancer cell hybrids to radiotherapy have been lacking. In this study, macrophage:MCF-7 hybrids were generated by spontaneous in vitro cell fusion. After irradiation, both hybrids and their maternal MCF-7 cells were treated with $0 \mathrm{~Gy}, 2.5 \mathrm{~Gy}$ and $5 \mathrm{~Gy}$ y-radiation and examined by clonogenic survival and comet assays at three time points ( $0 \mathrm{~h}, 24 \mathrm{~h}$, and $48 \mathrm{~h})$. Compared to maternal MCF-7 cells, the hybrids showed increased survival fraction and plating efficiency (colony formation ability) after radiation. The hybrids developed less DNA-damage, expressed significantly lower residual DNA-damage, and after higher radiation dose showed less heterogeneity in DNA-damage compared to their maternal MCF-7 cells. To our knowledge this is the first study that demonstrates that macrophage:cancer cell fusion generates a subpopulation of radioresistant cells with enhanced DNA-repair capacity. These findings provide new insight into how the cell fusion process may contribute to clonal expansion and tumor heterogeneity. Furthermore, our results provide support for cell fusion as a mechanism behind the development of radioresistance and tumor recurrence.

\section{INTRODUCTION}

Accumulating evidence suggests that cell fusion between tumor associated macrophages and cancer cells may be an underlying cause of tumor progression. The fusion process generates hybrids that acquire genetic and phenotypic characteristics from both maternal cells and exhibit a metastatic phenotype [1,2]. Macrophage traits in tumor cells, such as CD163 expression, are reported in breast cancer and are associated with early tumor recurrence and reduced patient survival [3-5]. Based on cell fusion theory, fusion between tumor-associated macrophages (TAM) and cancer cells yields hybrid cancer cells with macrophage phenotype [6-8]. Spontaneous cell 
fusion is a complicated cellular process that occurs in solid tumors at low rates, but it is likely to increase under certain conditions such as radiation and inflammation [8-11].

Radiotherapy (RT) kills cancer cells by inducing DNA-damage, either directly or by creating free radicals that in turn damage the DNA. RT also initiates multiple signal transduction cascades regulating apoptosis as well as DNArepair, dictating the final fate of the cancer cell [12-14]. Breast cancer (BRC) is the most common tumor in females with an incidence of $94 / 100000$ and a mortality rate of 23/100 000 cases annually [15]. Breast conserving surgery (BCS) in combination with postoperative radiotherapy (RT) is an established treatment of BRC and shown to result in equivalent disease-free and overall survival rates as compared to mastectomy [16]. The purpose of RT is to eliminate microscopic tumor foci in the conserved breast. In spite of radical resection of $\mathrm{BRC}$ and postoperative $\mathrm{RT}$, ipsilateral local recurrence (ILR) of the primary tumor occurs in about $10 \%$ of females after BCS and is associated with increased risk of distant metastases and poor survival [17-20]. Tumor recurrence is suggested to be caused by the selection of therapy resistant cell clones, which in later stages of disease become a source of tumor recurrence and metastasis [21, 22].

Intra-tumoral heterogeneity is an important phenomenon in tumor biology and generates subpopulations of cancer cells that may be resistant to oncologic treatment and contribute to tumor growth [23-25]. The mechanisms of resistance and clonal heterogeneity in cancer remain enigmatic and pose challenges for oncologic treatment. Accumulating evidence suggests that cell fusion in cancer constitutes a source of heterogeneity and generates treatment-resistant hybrid cells [26-30].

In this study we investigate the role of cell fusion between human M2-macrophages and breast cancer cells in the development of malignant cell clones (macrophage:MCF-7 hybrids) resistant to RT. The study utilizes alkaline single cell gel electrophoresis (SCGE), or comet assay, a reliable method for detecting radiation-induced DNA-damage and repair at a single cell level [31, 32]. Our aim is to increase our understanding of the role of cell fusion in the development of radiation resistance and its possible contribution to tumor recurrence in breast cancer.

\section{RESULTS}

\section{Generation and definition of hybrids}

Macrophage:MCF-7 hybrids were generated spontaneously by co-culturing MCF-7 cancer cells with M2-differentiated macrophages. GFP-/CD163+/CD45+ cells were defined as M2-macrophages. GFP+/CD163+/ CD45+ cells were defined as hybrids and GFP+/CD163-/ CD45- cells were defined as MCF-7 cancer cells. Dot plots are demonstrated in Figure 1. The proportion of hybrids harvested by fluorescence-activated cell sorting (FACS) was approximately $2 \%$.

\section{Hybrids showed higher cell survival and cloning efficiency following radiation than maternal MCF-7 cells}

Survival fraction (SF) was investigated by clonogenic assay after radiation doses of 0 Gy (control), 2.5 Gy and 5 Gy. In both MCF-7 cells and hybrids, the SF was inversely proportional to the radiation dose. The mean survival fraction for MCF-7 cells was $52 \%$ at 2.5 Gy and $9.5 \%$ at 5 Gy while the corresponding results for hybrids were $58 \%$ and $14 \%$, respectively. The hybrids showed distinctly higher survival fractions than MCF-7 cells at both 2.5 Gy and 5 Gy radiation, statistically significant at 5 Gy $(p=0.006)$ (Figure 2A).

The plating efficiency (PE) was measured to test colony forming ability of MCF-7 and hybrids after 2.5 Gy and $5 \mathrm{~Gy}$, compared to untreated cells. The mean PE for untreated MCF-7 cells was $46 \%$ which was significantly lower compared to the mean PE for hybrids $(60 \%$; $p=0.001)$. The mean PE of MCF-7 decreased significantly to $26 \%$ and $4 \%$ at radiation doses of $2.5 \mathrm{~Gy}$ and $5 \mathrm{~Gy}$, respectively. The mean $\mathrm{PE}$ for hybrids continued to be high $(62 \%, p<0.001)$ at radiation dose of 2.5 Gy. Interestingly, the mean PE of MCF-7 and hybrids decreased to similar levels at a radiation dose of $5 \mathrm{~Gy} ; 4 \%$ and $6 \%$, respectively (Table 1). There was no significant difference in mean PE between the cells at 5 Gy (Figure 2B).

\section{Less radiation-induced DNA-damage in hybrids than in maternal MCF-7 cells}

Extent of radiation-induced DNA-damage was analyzed by SCGE using alkaline electrophoresis, quantified as an increase in tail moment (TM), which is proportional to the number of DNA strand breaks per cell [33]. Representative images of MCF-7 and hybrid comets, evaluated before and after radiation, are shown in Figure 3.

Immediately $(0 \mathrm{~h})$ after 2.5 Gy radiation, the hybrids showed significantly lower DNA-damage (mean TM of $673 \pm$ SEM 47) compared to MCF-7 cells (mean TM of $835 \pm \mathrm{SEM} 45 ; p<0.001)$. However, 5 Gy radiation induced significantly higher mean TM (1460 \pm SEM 46) in hybrids compared to MCF-7 cells (1241, \pm SEM 79.5), and the comets developed in equal extent in both cell types. Twenty-four hours after 2.5 Gy and 5 Gy radiation, the difference in mean TM between the cell types was not significant (Figure 4). At 48 hours after 2.5 Gy and 5 Gy radiation, the mean TM decreased in both cell types significantly compared to mean TM at 0 and 24 hours (Table 2).

\section{Kinetics of DNA-repair}

In order to investigate the kinetics of DNA-repair, the changes in the residual DNA-damage (RDD) in MCF-7 cells and hybrids were calculated $24 \mathrm{~h}$ and $48 \mathrm{~h}$ after 
Table 1: Plating efficiency of MCF-7 and macrophage:MCF-7 cell hybrids in relation to radiation

\begin{tabular}{|c|c|c|c|c|}
\hline \multirow[t]{2}{*}{ Cell type } & \multirow[t]{2}{*}{ Radiation dose } & \multicolumn{3}{|c|}{ Plating efficiency (\%) } \\
\hline & & Mean & SEM & (p-value) \\
\hline \multirow[t]{3}{*}{ MCF7 } & 0 Gy & 0.46 & 0.03 & \\
\hline & $2.5 \mathrm{~Gy}$ & 0.26 & 0.01 & $<0.001$ \\
\hline & 5 Gy & 0.04 & 0.002 & $<0.001$ \\
\hline \multirow[t]{3}{*}{ Hybrids } & 0 Gy & 0.6 & 0.02 & \\
\hline & $2.5 \mathrm{~Gy}$ & 0.6 & 0.03 & 1 \\
\hline & 5 Gy & 0.06 & 0.01 & $<0.001$ \\
\hline
\end{tabular}

Table 2: DNA-damage measured as tail moment (TM) of MCF-7 cells and macrophage:MCF-7 hybrids in relation to $0 \mathrm{~Gy}$ (control), $2.5 \mathrm{~Gy}$ and $5 \mathrm{~Gy}$ radiation doses and post-radiation time (0, 24 and 48 hours)

\begin{tabular}{|c|c|c|c|c|c|}
\hline & $\begin{array}{l}\text { Radiation dose } \\
\text { (Gy) }\end{array}$ & $\begin{array}{l}\text { Repair time } \\
\text { (h) }\end{array}$ & $\begin{array}{c}\text { No. of comets per } 150 \\
\text { cell }(\%)\end{array}$ & $\begin{array}{c}\text { Tail moment } \\
\text { Mean }( \pm \text { SEM })\end{array}$ & $P$ \\
\hline \multirow[t]{8}{*}{ MCF-7 } & $0 \mathrm{~Gy}$ & control & $4(2.7)$ & $25(11.6)$ & \\
\hline & $2.5 \mathrm{~Gy}$ & 0 & $150(100)$ & $835(45)$ & \\
\hline & & 24 & $134(89)$ & $945(116)$ & 0.55 \\
\hline & & 48 & $126(84)$ & $480(31)$ & 0.002 \\
\hline & & & & & \\
\hline & 5 Gy & 0 & $150(100)$ & $1241(79.5)$ & \\
\hline & & 24 & $150(100)$ & $1028(57)$ & 0.024 \\
\hline & & 48 & $143(95)$ & $296(16)$ & $<0.001$ \\
\hline \multirow[t]{7}{*}{ Hybrids } & 0 Gy & control & $47(31)$ & $92(15.6)$ & \\
\hline & $2.5 \mathrm{~Gy}$ & 0 & $129(86)$ & $673(47)$ & \\
\hline & & 24 & $145(97)$ & $774.6(44)$ & 0.16 \\
\hline & & 48 & $86(57)$ & $163(19)$ & $<0.001$ \\
\hline & 5 Gy & 0 & $150(100)$ & $1460(46)$ & \\
\hline & & 24 & $150(100)$ & $917(45)$ & $<0.001$ \\
\hline & & 48 & $150(100)$ & $661(29)$ & $<0.001$ \\
\hline
\end{tabular}

radiation. The results are expressed as \%tail DNA of initial DNA-damage in untreated cells ( 0 Gy and 0 h). The RDD in both MCF-7 cells and hybrids was highest immediately after irradiation $(0 \mathrm{~h})$ compared to untreated cells and to treated cells at $24 \mathrm{~h}$ and $48 \mathrm{~h}$ after radiation. Compared to RDD values $24 \mathrm{~h}$ after treatment, the RDD in MCF-7 cells increased after 2.5 Gy and 5 Gy radiation at $48 \mathrm{~h}$. RDD in MCF-7 cells, at $0 \mathrm{~h}-48 \mathrm{~h}$, was higher after 5 Gy compared to 2.5 Gy radiation. Hybrids treated with 2.5 Gy radiation expressed significantly higher RDD at $48 \mathrm{~h}$ than at $24 \mathrm{~h}(90 \%$ vs $86 \% ; p=0.001)$. However, interestingly, the RDD in hybrids irradiated with 5 Gy was significantly lower at $48 \mathrm{~h}$ than at $24 \mathrm{~h}$ after radiation ( $70 \%$ vs $77 \% ; p=0.017)$ (Table 3 ).

\section{Heterogeneity in DNA-damage}

Heterogeneity of DNA-damage was estimated by variance of TM for each radiation dose. The heterogeneity of TM in both MCF-7 and hybrid cells increased significantly immediately after radiation $(p=0.001)$ (Figure 5A). The mean variance of TM in MCF-7 cells after 5 Gy was considerably greater than that after $2.5 \mathrm{~Gy}$, whereas the TM variance in hybrids was similar after 2.5 Gy and 5 Gy. The MCF-7 cells showed significantly higher TM variance compared to hybrids after 5 Gy radiation, but after 2.5 Gy the TM variance was approximately equal in both cell types (Figure 5B). 

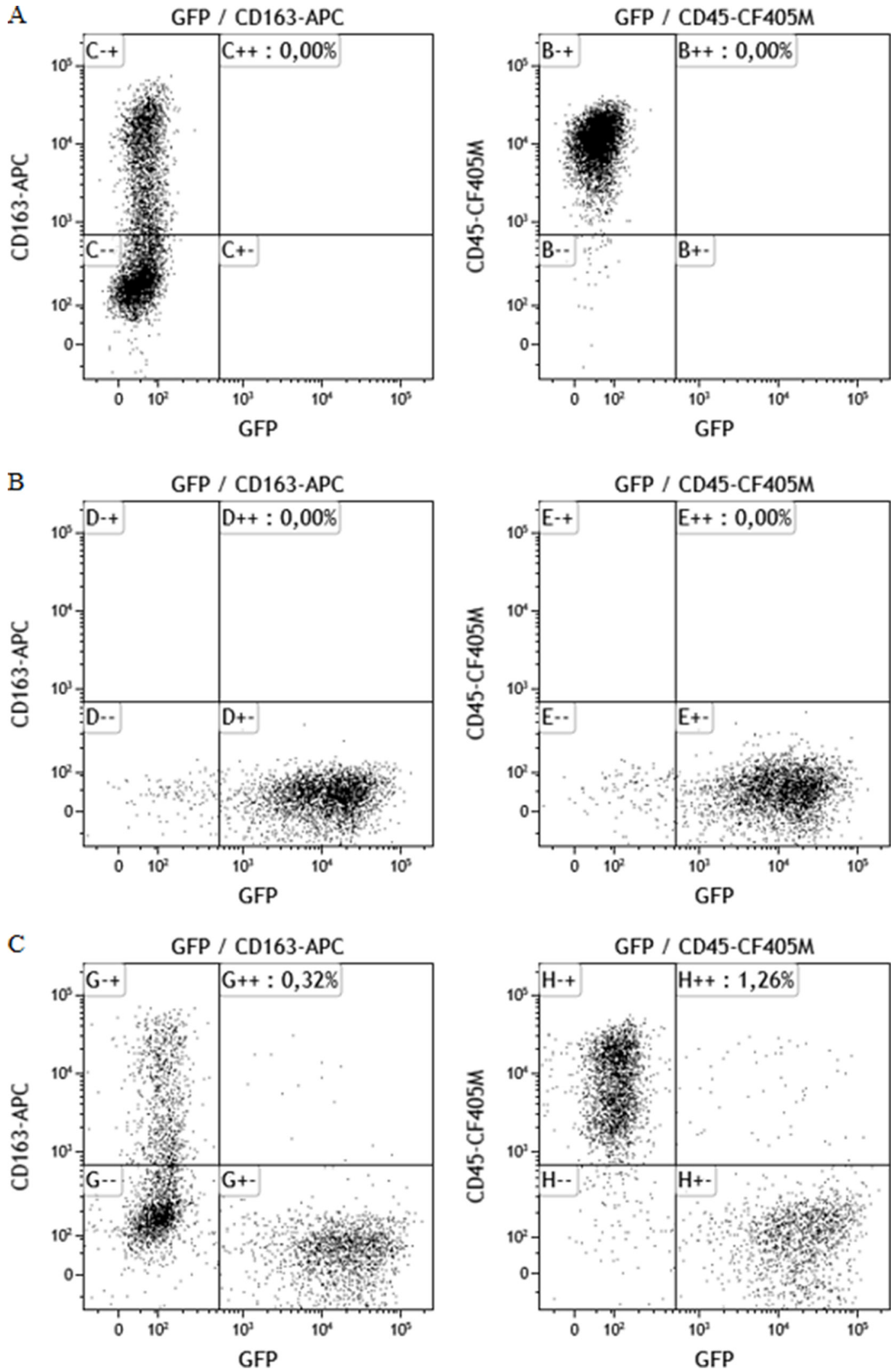

Figure 1: Dot plots showing cellular staining of CD163, CD45 and GFP. All plots show events previously gated in a side scatter and forward scatter plot (showing size and granularity of the cells) to ensure populations based on events consisting of single cells only. (A) Macrophages cultures show CD45+/CD163+/GFP-, (B) MCF-7/GFP cells, transfected with the GFP gene show no positive staining for CD163 or CD45, (C) Co-cultures of MCF-7 cells and macrophages yield a MCF-7 population (GFP+), a macrophage population (CD163+/ $\mathrm{CD} 45+)$ and a double positive hybrid population (CD163+/CD45+/GFP+). 


\section{DISCUSSION}

Clonal evolution in solid tumors contributes to intratumoral heterogeneity and results in the development of subpopulations of cancer cells with different responses to oncological treatment [34-36]. In this study, we demonstrate that fusion between M2-macrophages and MCF-7 breast cancer cells generate hybrid cells that show less DNAdamage, decreased residual DNA-damage, and exhibit extended survival compared to their maternal MCF-7 cancer cells after radiation. The study is based on the SCGE, which is a reliable method that offers a technique for detecting radiation induced DNA damage and repair at single cell level. The advantage of this in vitro experimental model is that the effect of radiation on hybrid cells and their maternal cancer cells can be investigated independently of other influencing mechanisms such as paracrine interactions with non-neoplastic cells in tumor microenvironment.
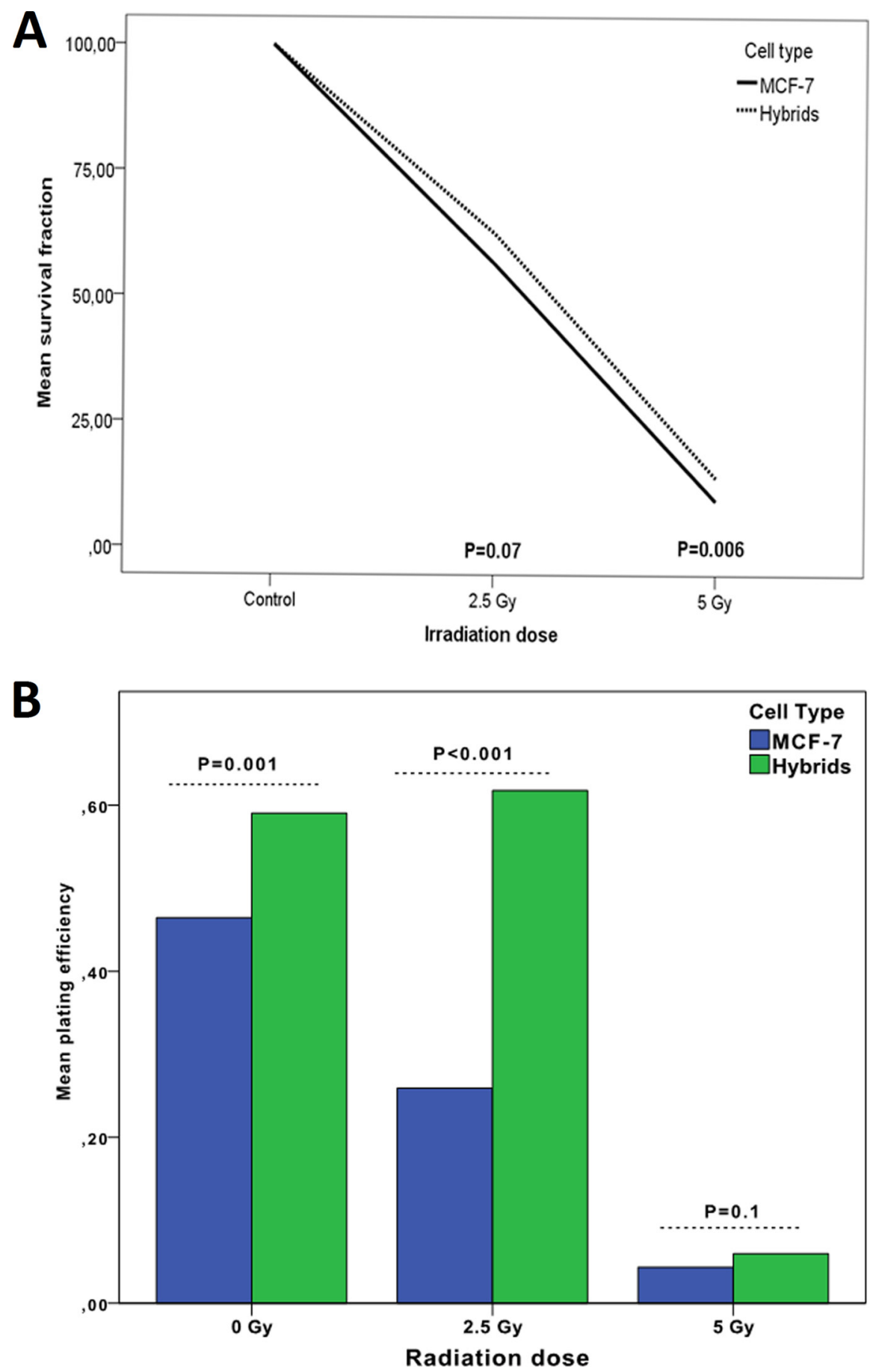

Figure 2: Survival fraction (A) and plating efficiency (B) of MCF-7 cells compared to macrophage:MCF-7 cell hybrids treated with 0-5 Gy $\gamma$-radiation. The 0 Gy value is considered as baseline value (control). 
Table 3: Kinetics of DNA-repair in MCF-7 cancer cells and macrophage:MCF-7 hybrids at 24 and 48 hours after $2.5 \mathrm{~Gy}$ and $5 \mathrm{~Gy}$ radiation dose, respectively

\begin{tabular}{|c|c|c|c|c|c|}
\hline & $\begin{array}{l}\text { Radiation } \\
\text { dose (Gy) }\end{array}$ & $\begin{array}{l}\text { Repair } \\
\text { time (h) }\end{array}$ & $\begin{array}{c}\text { \% Tail DNA } \\
\text { Mean }( \pm \text { SEM })\end{array}$ & $\begin{array}{c}\% \text { of residual tail } \\
\text { DNA }\end{array}$ & $P$-value \\
\hline \multirow[t]{7}{*}{ MCF-7 } & 0 Gy & 0 & $0.7(0.3)$ & & \\
\hline & $2.5 \mathrm{~Gy}$ & 0 & $11(0.4)$ & $1571^{*}$ & $<0.001 *$ \\
\hline & & 24 & $19(0.9)$ & 90 & \\
\hline & & 48 & $21(1)$ & 105 & $<0.001$ \\
\hline & 5 Gy & 0 & $34(0.8)$ & $4857^{*}$ & $<0.001 *$ \\
\hline & & 24 & $25(0.8)$ & 190 & \\
\hline & & 48 & $21(0.9)$ & 205 & 0.001 \\
\hline \multirow[t]{7}{*}{ Hybrids } & 0 Gy & 0 & $8(1)$ & & \\
\hline & $2.5 \mathrm{~Gy}$ & 0 & $18(0.9)$ & $225^{*}$ & $<0.001 *$ \\
\hline & & 24 & $22(1)$ & 86 & \\
\hline & & 48 & $18(0.7)$ & 90 & 0.001 \\
\hline & 5 Gy & 0 & $35(0.9)$ & $437^{*}$ & $<0.001^{*}$ \\
\hline & & 24 & $29(1)$ & 77.5 & \\
\hline & & 48 & $27(0.6)$ & 70 & 0.017 \\
\hline
\end{tabular}

* $P$-value for differences between the cells at $2.5 \mathrm{~Gy} 0 \mathrm{~h}$ vs $0 \mathrm{~Gy} 0 \mathrm{~h}$ and at $5 \mathrm{~Gy} 0 \mathrm{~h}$ vs $0 \mathrm{~Gy} 0 \mathrm{~h}$.

\section{Cell fusion is associated with resistance to oncologic treatment}

Tumor cells are fusogenic and they fuse with other cancer cells and non-neoplastic cells in tumor stroma. Spontaneous fusion between cancer cells is a well documented phenomenon in solid tumors and generates heterogeneous subpopulation of cells that exhibit resistance to chemotherapy [37-40]. Heterotypic cell fusion occurs between cancer cell and bone marrow derived cells, like macrophages, and results in hybrids with increased metastatic features $[1,37-39]$. In this study, the hybrids expressed phenotypic traits from both maternal cells, which is consistent with previous observations reported by our group and other in vitro and in vivo studies [7, 8, 10, 41-43]. The hybrids exhibited higher survival fraction and plating efficiency following radiation compared to maternal MCF-7. Colony formation in cancer cells is an important characteristic for survival and dissemination. DNA-damage is not always lethal to the cell. Rather, tumor cells exposed to DNA-damaging agents may be inactivated [44-46], exhibiting decreased proliferation. In cancer cells, the extent of radiation induced cell division delay is influenced by the cell cycle phase in which the cells are. Cells irradiated in $\mathrm{S}$ and G2 phases demonstrate greater division delay than cells in G1. The greater the number of proliferating cells in tumor stroma, the more radiosensitive a tumor will be [47-49]. Moreover, DNA-repair is less efficient during S-phase compared to other phases in cell cycle [50-53]. Several reports indicate that fusion between cancer cells induces cellular senescence and generate slowly growing (dormant) hybrid cells that become non-apoptotic and resistant to chemo- and radiotherapy [54-56]. Hybrids, generated by fusion between cancer cells and bone marrow derived cells, show growth inhibition often in combination with enhanced metastatic properties [57, 58]. Hence, cell fusion may induce growth inhibition with fewer cancer cells in S-phase, contributing to more efficient DNA-repair capacity and less DNA residual damage. These growth arrested cells might remain viable and contribute to cancer recurrence by later generating repopulating tumor cell progeny [59-61]. Taken together, these observations are coherent with the findings presented in this study and suggest that hybrids exposed to radiation might remain viable and retain colony formation ability. Thus, the fusion 
between macrophages and cancer cells may represent a significant mechanism contributing to the development of treatment resistance in tumor cells.

Another molecular mechanism involved in radiotherapy resistance in hybrid cells may involve regulation of reactive oxygen species (ROS). Ionizing radiation generates $\mathrm{ROS}$, which are reactive with several cellular macromolecules, including DNA, and promote genomic instability by causing accumulation of mutations [62]. ROS-scavengers eliminate ROS and counteract the toxic effects of radiation. Since ROS play an important role in radiation-induced cell death, it is logical to suggest that ROS-scavengers might be involved in hybrid cell response to radiation. In cancer cells with acquired radiation resistance, all classes of ROS-scavengers are up-regulated. On the other hand, downregulation of ROS-scavengers increases the level of ROS and results in improved response of the tumor cells to radiation [63-65]. For example, Ape1/ Ref1 is a ROS-scavenger protein that acts as a DNA repair enzyme. In breast and prostate cancer cell lines, overexpression Ape1/Ref1 is associated with restoration of radiation sensitivity and enhanced DNA repair [64, $66,67]$. One hypothesis is therefore that hybrid cells can effectively diminish radiation-induced ROS-formation and ROS-induced DNA damage by activating ROSscavenging machinery. Reduced intracellular ROS content would decrease radiation-induced DNA damage, enhance DNA repair, and contribute to radiation resistance [68].

\section{Cell fusion, radiation and DNA-damage}

Ionizing radiation has genotoxic effects on cancer cells by directly damaging the molecular structures of DNA and consequently inhibits cell proliferation and induces cell death. DNA-repair pathways recognize and remove the genomic lesions, but unrepaired DNAdamage will in most cases induce cellular senescence or apoptosis $[69,70]$.

\section{Radiation}
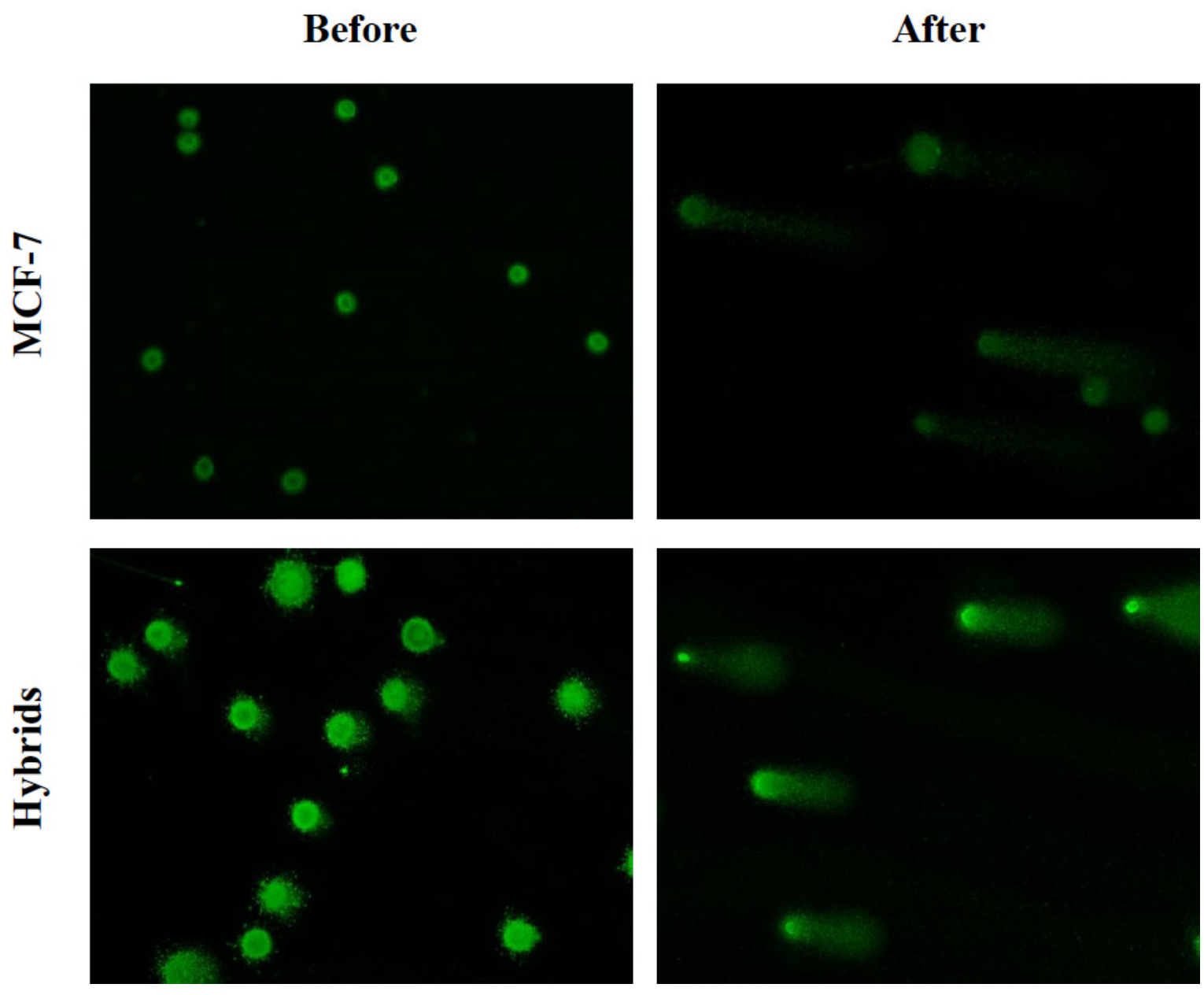

Figure 3: Images after alkaline SCGE demonstrating MCF-7 cells and macrophage:MCF-7 cells hybrids before and after radiation. DNA-damage appears as fluorescent comets (tails), originating from cell nucleoids as migrating DNA fragments. Image analysis was performed by ZEN 2.3 software (Bergman Labora Nikon Eclipse E600, Nikon Digital Sight DS-US camera) and NIS Elements $\mathrm{BR}$, Nikon. The images are captured in $\times 20$ magnification. 
To our knowledge, there are no previous studies investigating how fusion of macrophages and cancer cells impacts the radiation response in solid tumors and more specifically in breast cancer. However, previous reports have shown that cell fusion generates cell clones (hybrids) with reduced susceptibility to other forms of oncological treatments. In an in vitro study, Yang et al (2010) reported that cell fusion among MCF-7 cancer cells could be induced by doxorubicin treatment and that MCF-7 hybrid cells acquired a doxorubicin-resistant phenotype [37]. Wang et al (2012) showed that spontaneous fusion between RL-1 prostate cancer cells and HPS-15 stroma
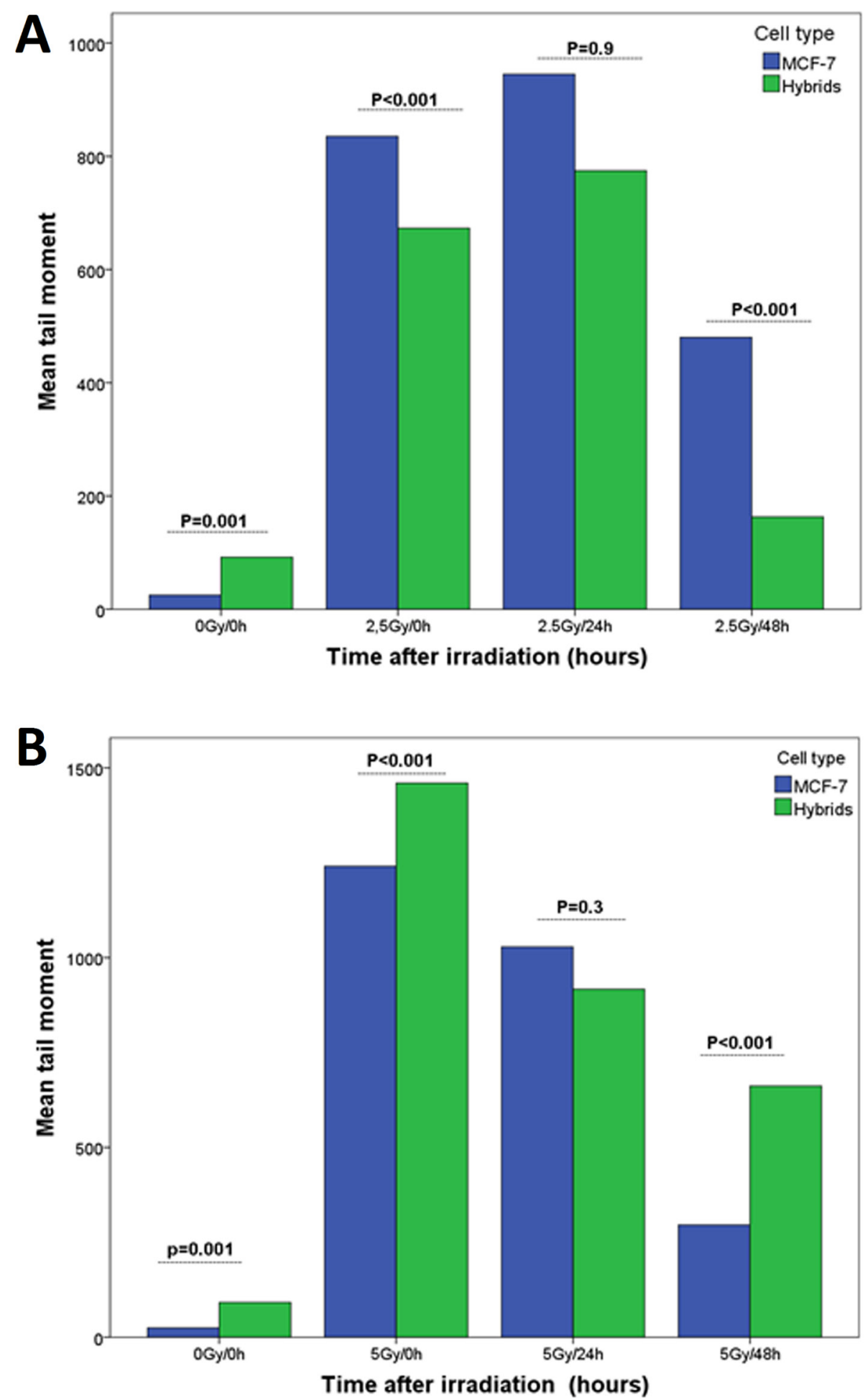

Figure 4: DNA-damage estimated as tail moment (TM) and measured by SCGE performed at three time points ( 0,24 and 48 hours) after radiation with (A) 2.5 Gy and (B) 5 Gy $\gamma$-radiation. 
A
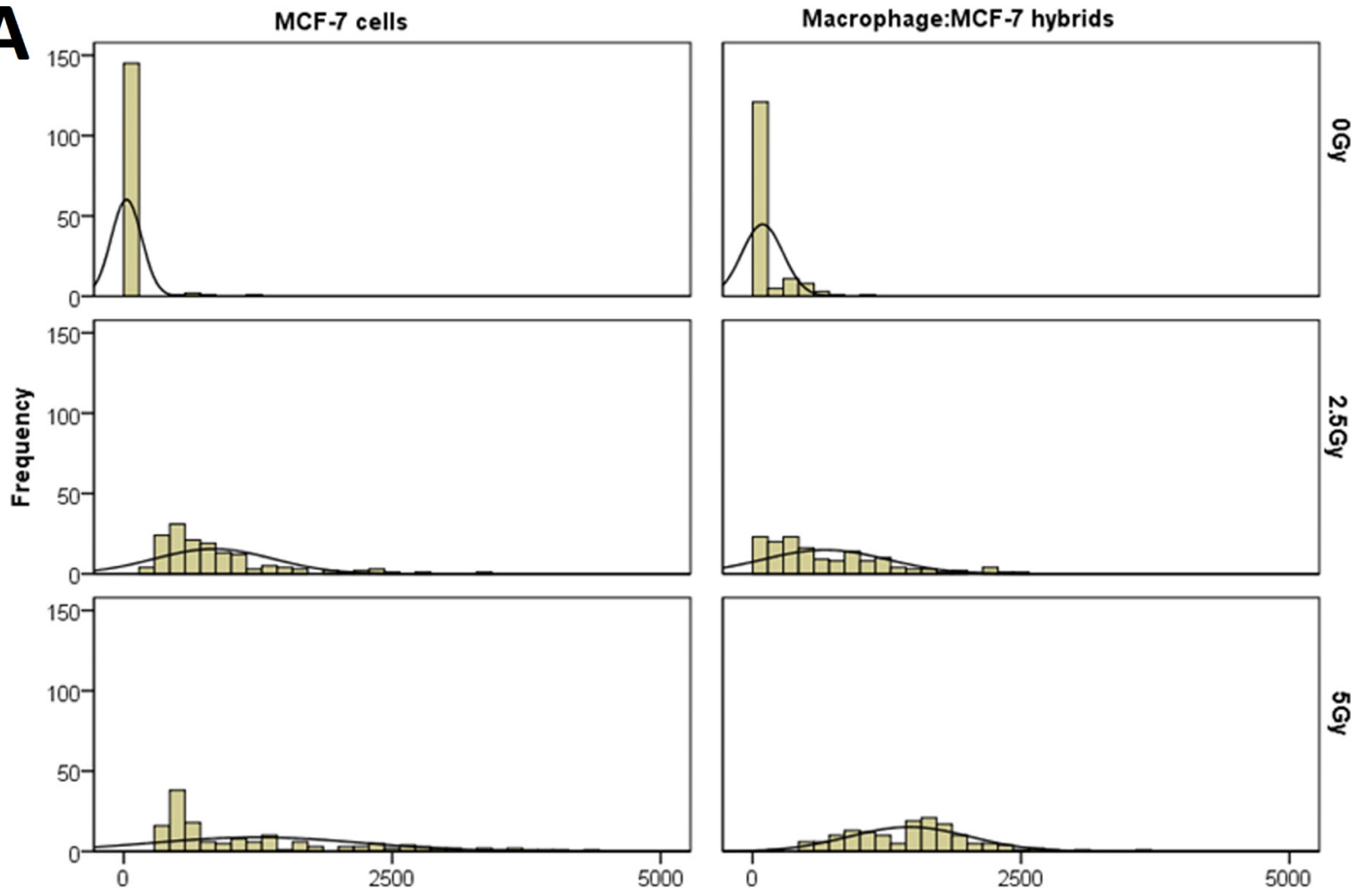

B

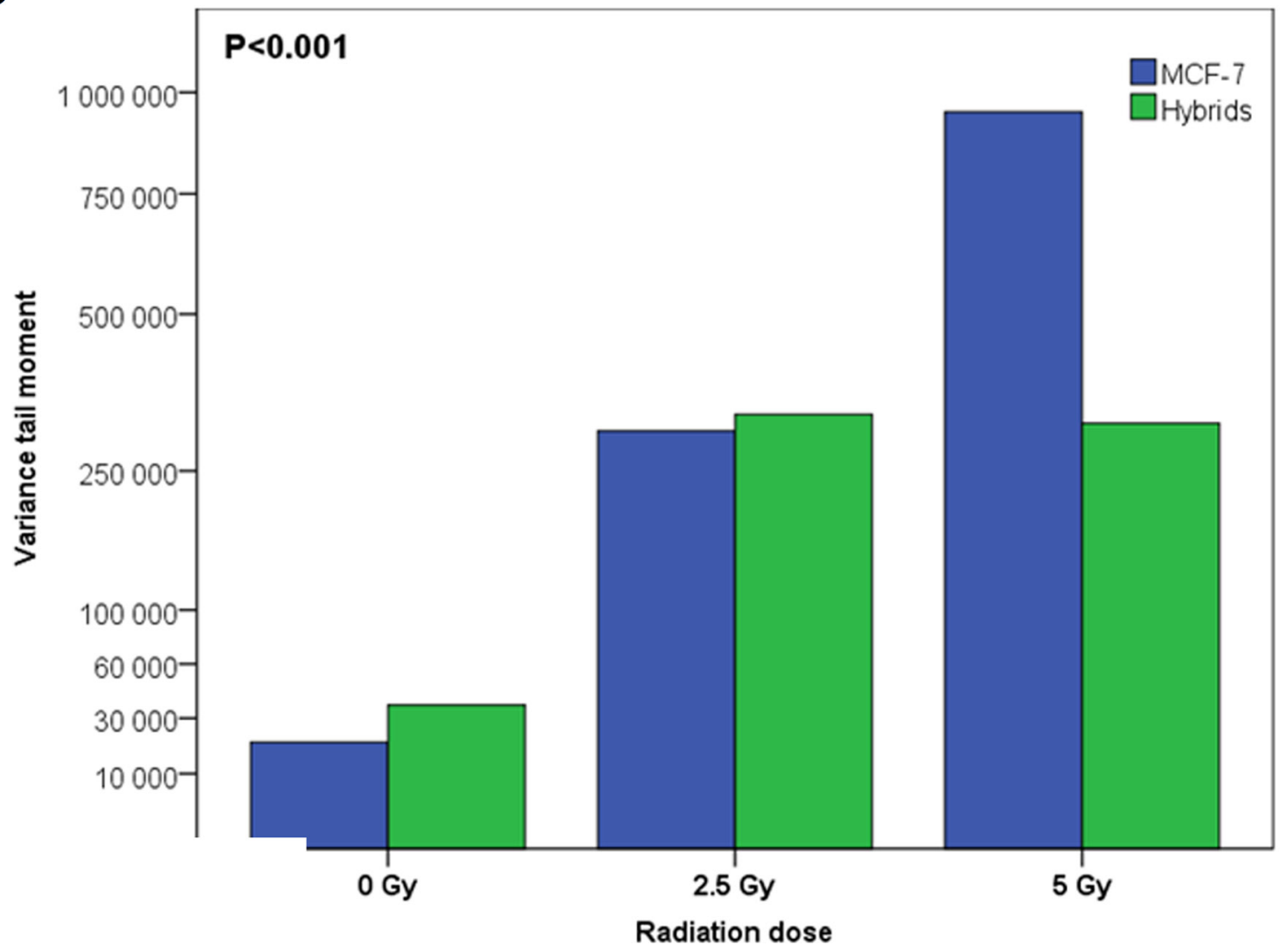

Figure 5: (A) The heterogeneity of DNA-damage in MCF-7 cells and macrophage:MCF-7 cells hybrid in relation to $\gamma$-radiation (0-5 Gy). (B) The variance in DNA-damage for MCF-7 and hybrids increased after radiation. In MCF-7 cells, the variance in DNA-damage was proportional to radiation dose but in hybrids remained unchanged at 2.5 Gy and 5 Gy. 
cells generated subpopulations of malignant cells that exhibited sustained androgen receptor expression during androgen deprivation and increased levels of prostate specific antigen (PSA) indicating androgen insensitivity and androgen independence [71]. Moreover, in an in vitro experiment, Kaur et al (2015) reported a high frequency of homotypic cell fusion in a glioblastoma cell line resulting in a hybrid subpopulation demonstrating decreased radiation-induced stress, increased senescenceassociated secretory proteins (SASPs), and upregulated anti-apoptotic genes like BIRC3 and Bcl-xL [55]. In the current study, the hybrids acquired significantly less DNA-damage after 2.5 Gy but similar levels of DNAdamage after 5 Gy radiation as compared to their maternal MCF-7 cells. These data suggest that higher radiation doses may be required to achieve genotoxic effects in hybrid cells.

\section{Kinetics of DNA-repair}

DNA-repair capacity is a predisposing factor in cancer susceptibility and influences radiosensitivity [72-75]. Compared to maternal MCF-7 cells, hybrids showed significantly lower residual DNA-damage immediately after radiation as well as 24 and 48 hours after exposure. In addition, the hybrids demonstrated significantly higher survival fractions than MCF-7 cells, especially after 5 Gy radiation dose. Taken together, these findings suggest that hybrids acquire enhanced DNA-damage recovery capacity and decreased radiosensitivity.

\section{Radiation damage heterogeneity}

Intratumoral heterogeneity is a hallmark of solid tumors, thought to arise through a complex evolution of genetic, epigenetic, and functional diversity in tumor cells as they interact in the tumor microenvironment [76-79]. Somatic cell fusion causes nuclear reprogramming with genetic and phenotypic diversity in tumors, which in turn contributes to the development of tumor heterogeneity $[80,81]$. In this paper, MCF-7 and hybrids showed significant heterogeneity in radiation induced-DNAdamage. While the variance of DNA-damages in MCF-7 cells was proportional to the radiation dose $(0-5 \mathrm{~Gy})$, the hybrids showed no significant difference in DNA-damage variance between 2.5 and $5 \mathrm{~Gy}$. Thus, DNA damage heterogeneity in hybrids is not proportional to radiation at doses of $2.5-5 \mathrm{~Gy}$, suggesting that hybrids might have greater genetic stability than MCF-7 cells.

\section{Cell fusion in human cancers and its clinical significance}

Cell fusion is a natural biological process in normal development and tissue regeneration. In vitro and in vivo experimental data indicate that cell fusion occurs in solid tumors and may play a significant role in clinical tumor progression [8, 82-85]. Silk et al (2013) provided clinical evidence for cell fusion between transplanted bone marrow derived cells and human intestinal epithelium [6]. In human cancers, it is difficult to confirm cell fusion because of the shared genetic content of macrophages, cancer cells, and hybrids and the lack of tissue specific markers indicative of fusion between the two cell types. However, by studying transplant patients it is possible to distinguish the genetic sources of the tumor cells and clinical evidence indicating leucocyte-tumor cell hybridization in human cancers has been demonstrated in several case reports. Chakraborty et al (2004) and Yilmaz et al (2005) both reported that in renal cell carcinoma patients who had previously received allogeneic bone marrow transplants (BMT), alleles from both donor and recipient were found in primary tumor cells, indicating that fusion between tumor cells and donor bone marrow derived cells had occurred [86, 87]. Lazova et al (2011) analyzed the genotype of a melanoma brain metastasis from a patient who had previously received an allogeneic BMT and found that tumor cells contained alleles from donor and patient pre-BMT lymphocytes with similar allelic ratios, suggesting that the tumor was generated from a single fusion event or hybrid cell clone [88]. In another case, a patient who received an allogeneic BMT and later developed malignant melanoma, the melanoma cells within the lymph node metastasis contained a mixture of the donor-patient genome, again suggesting hybridization between donor bone marrow derived cells and patient tumor cells [89]. These observations constitute clinical evidence for leucocyte-cancer cell hybrid formation in human cancers.

Based on the cell fusion theory and the assumption that macrophage-cancer cell fusion creates hybrids expressing phenotypic characteristics of macrophages, we used the macrophage-specific marker CD163 as a surrogate marker for detecting fusion events in a clinical tumor material. CD163 was expressed by tumor cells in $48 \%$ of breast and $20 \%$ of colorectal cancer patients and was significantly associated with advanced tumor stages and poor survival $[3,4,90]$. In rectal cancer patients, CD163 expression in tumor cells was found in $17 \%$ of primary tumors from patients not treated with preoperative irradiation compared with $31 \%$ of those given preoperative radiotherapy ( $\mathrm{p}<0.044)$. Moreover, CD163 expression was inversely correlated to apoptosis. In tumors from patients treated with preoperative radiotherapy, apoptosis was significantly higher in CD163-negative tumors. There was no correlation between CD163 expression and apoptosis in tumors from patients who did not receive preoperative radiotherapy [4]. These observations from clinical human tumor material suggest that cell fusion may influence tumor biology including response to radiotherapy. 


\section{MATERIALS AND METHODS}

\section{Cell culture}

MCF-7/GFP (AKR-211) breast cancer cell line (Cell Biolabs, INC. San Diego, USA) was cultured in Roswell Park Memorial Institute (RPMI) 1640 medium supplemented with $1 \%$ penicillin-streptomycin (PEST) (Thermo Fisher Scientific, USA), 10\% FBS, 2.5\% HEPES and GlutaMax $\left(\right.$ Gibco $^{\circledR}$, Life Technologies, USA) in T-75 tissue culture flasks (431464, Corning Incorporated, Sigma-Aldrich Co, ST. Louis, USA) and incubated at $37^{\circ} \mathrm{C}$ in humidified air $5 \% \mathrm{CO}_{2}$ atmosphere. Cell medium was changed every $2-3$ days, and the cells were passaged with $0.25 \%$ trypsin $\left(\mathrm{Gibco}^{\circledR}\right.$, Life Technologies, USA) at $95 \%$ confluence.

\section{Monocyte isolation}

Monocytes were isolated from buffy coat obtained from male healthy blood donors at the department of Transfusion Medicine, County Council of Östergötland, in Linköping and Jönköping, Sweden. All the blood donors had given their informed consent according to the local guidelines and the Swedish National Law on ethical review of research involving humans (2003:460: 3-4 $\S)$. The buffy coat was mixed with $70 \mathrm{ml} \mathrm{NaCl}$, layered onto $20 \mathrm{ml}$ Lymphoprep (Thermo Fisher Scientific, Waltham, MA USA) in $50 \mathrm{ml}$ centrifuge tubes $(91050$, Techno Plastic Products, Switzerland) and centrifuged (without brake) at $480 \mathrm{~g}$ (Sigma Laboratory $4 \mathrm{k} 15$ ) in room temperature for 40 minutes. The buffy coat layer, generated on top of the Lymphoprep layer, was transferred into new $50 \mathrm{ml}$ tubes containing PBS-Heparin (Medicago Leo Pharma, Denmark) and filled to total volume of 50 $\mathrm{ml}$ with PBS-Heparin and centrifuged at $300 \mathrm{~g}$ for 10 minutes at $4^{\circ} \mathrm{C}$. The cell pellets were washed twice in PBS-Heparin, centrifuged at $220 \mathrm{~g}$ for 5 minutes at $4^{\circ} \mathrm{C}$, followed by three washing procedures in Krebs-Ringer Bicarbonate Buffer (consisting of $120 \mathrm{mM} \mathrm{NaCl}, 4.9 \mathrm{mM}$ $\mathrm{KCl}, 1.2 \mathrm{mM} \mathrm{MgSO}{ }_{4} \times 7 \mathrm{H}_{2} \mathrm{O}, 1.7 \mathrm{mM} \mathrm{KH_{2 }} \mathrm{PO}_{4} \times 2 \mathrm{H}_{2} \mathrm{O}$ and $10 \mathrm{mM}$ Glucose) without $\mathrm{Ca}^{2+}$ and centrifuged at $220 \mathrm{~g}$ for 5 minutes at $4^{\circ} \mathrm{C}$. The white blood cells were resuspended in $20 \mathrm{ml}$ RPMI1640 medium supplemented with $1 \%$ PEST. The number of cells was established using a TC10 ${ }^{\mathrm{TM}}$ Automated Cell Counter (Bio-Rad Laboratories AB, Solna, Sweden) and seeded into T-75 tissue culture flasks (431464, Corning Incorporated, Sigma-Aldrich Co, ST. Louis, USA) with RPMI 1640 medium ( $10 \mathrm{ml}$ total volume), supplemented with $1 \%$ PEST, and incubated for $1-2 \mathrm{~h}$ at $37^{\circ} \mathrm{C}$ with $5 \% \mathrm{CO}_{2}$ to allow monocyte adhesion. The non-adherent cells were eliminated by washing 2-3 times using PBS $37^{\circ} \mathrm{C}$. The adherent monocytes were allowed to differentiate to macrophages due to incubation (at $37^{\circ} \mathrm{C}$ in $5 \% \mathrm{CO}_{2}$ ) with $40 \mathrm{ng} / \mathrm{ml}$ of macrophage colonystimulating factor, M-CSF (Nordic Biosite, Sweden), for
5-7 days. Induction of M2 polarization of macrophages, the M-CSF differentiated macrophages were stimulated with $20 \mathrm{ng} / \mathrm{ml}$ human interleukin-4 (IL-4) (Nordic Biosite, Sweden) for $18-24 \mathrm{~h}$ at $37^{\circ} \mathrm{C}$ and $5 \% \mathrm{CO}_{2}$.

\section{Generating and isolation of M2- macrophage:MCF-7 hybrids}

Spontaneous cell fusion between M2-macrophages and GFP-labeled MCF-7 cancer cells was induced by co-culturing these cells in the same cell culture vial (T-25 and/or T-75, 430168/431464, culture flasks, Corning Incorporated, Sigma-Aldrich Co, ST. Louis, USA) in RPMI 1640 medium, $37^{\circ} \mathrm{C}$ in $5 \% \mathrm{CO}_{2}$ during 2-3 days. The cells were seeded at a ratio of about 3-5:1 (M2-macrophages: MCF-7). After hybridization, cells were harvested with a $0.05 \%$ trypsin-EDTA solution (Gibco ${ }^{\circledR}$, Life Technologies, USA), centrifuged at $300 \mathrm{~g}$ for 5 minutes at $4^{\circ} \mathrm{C}$ in $1,5 \mathrm{ml}$ eppendorf tubes (Eppendorf) washed with $1 \mathrm{ml}$ PBS $4^{\circ} \mathrm{C}$, and resuspended in $95 \mu \mathrm{l}$ Cell Staining Buffer (Nordic Biosite, Sweden) at a concentration of about $5 \times 10^{6}$ cells $/ \mathrm{ml}$. The cell suspension was incubated on ice for $10 \mathrm{~min}$ with $5 \mu \mathrm{l}$ TrueStain FcX solution (BioLegend, San Diego, USA) per $1 \times 10^{6}$ cells. Combinations of direct conjugated monoclonal anti-human CD163 (APC Anti-human CD163 (IgG1 k), clone GHI/61, $100 \mu \mathrm{g} / \mathrm{ml}$ ) and anti-human CD45 (CF405M anti-human CD45 (IgG1 k), clone HI30, $50 \mu \mathrm{g} /$ $\mathrm{ml}$ ) antibodies or their respective isotype controls (APC and CF405M mouse IgG1 k, clone MOPC-21, $200 \mu \mathrm{g} /$ ml) (all antibodies from Biolegend, San Diego, USA) were added to the cell suspension at concentrations recommended by the manufacturer and incubated at $4{ }^{\circ} \mathrm{C}$ for $30 \mathrm{~min}$ in darkness. The samples were centrifuged at $300 \mathrm{~g}$ for 5 minutes at $4^{\circ} \mathrm{C}$ and excess of antibodies was removed with supernatant. The labeled cells were washed twice in $1 \mathrm{ml}$ Cell Staining Buffer/centrifuged at $300 \mathrm{~g}$ for 5 minutes at $4{ }^{\circ} \mathrm{C}$, diluted in $1 \mathrm{ml} \mathrm{PBS}$ and filtrated in pre-separation filter ( $30 \mu \mathrm{m}$, Miltenyi Biotech, Lund, Sweden) before they were sorted with BD FACSAria ${ }^{\mathrm{TM}}$ III (BD Bioscience, USA) (violet laser $405 \mathrm{~nm}$, blue laser 488 $\mathrm{nm}$, green laser $561 \mathrm{~nm}$, red laser $632 \mathrm{~nm}$ ). The cells were examined in relation to GFP, CD163 and CD45 expression and initially sorted by GFP expression (positive selection of MCF-7/GFP origin) and subsequently by CD163 and CD45 expression. Macrophage:MCF-7 hybrids expressed both GFP and macrophage marker (CD163 and CD45) and cells positive for these markers were collected in tubes (352063, BD Falcon ${ }^{\mathrm{TM}}$, Thermo Fisher Scientific) containing $0.5 \mathrm{ml} \mathrm{FBS}$ at $4^{\circ} \mathrm{C}$.

\section{Radiation}

MCF-7 cells and M2-macrophage:MCF-7 hybrids $\left(5 \times 10^{5}\right.$ cells $)$ were cultured in T-25 tissue (430168, Corning Incorporated, Sigma-Aldrich Co, 
ST. Louis, USA) culture flasks in complemented RPMI 1640 medium, allowed to grow for 2 days (90-95\% confluency). At day 3 after seeding, the cells were exposed to gamma, $\gamma$, radiation (Clinac $600 \mathrm{C} / \mathrm{D}$, Varian Medical Systems Incorporated, Herlev, Denmark, one AP field, linear accelerated 6MV Photons) with dose rate $5 \mathrm{~Gy} /$ minute and doses of 0 (control), 2.5 and 5.0 Gy at room temperature. The culture flasks were surrounded with $3 \mathrm{~cm}$ poly methyl methacrylate (PMMA) with density in comparison with human tissue. For the evaluation of initial damage, immediately after irradiation, the samples were kept on ice to avoid repair of irradiation induced damage ( $0 \mathrm{~h}$, no incubation period). For repair evaluation and view cell recovery from the effects of radiation over time, the cells were incubated at $37^{\circ} \mathrm{C}$ in humidified air $5 \% \mathrm{CO}_{2}$ atmosphere for 24 and 48 hours, respectively, after irradiation and prior to examination with alkaline single cell gel electrophoresis (SCGE) and clonogenic assays.

\section{Alkaline single cell gel electrophoresis (SCGE)}

The alkaline single cell gel electrophoresis (SCGE), also called comet assay, is an established technique for quantifying DNA damage in individual cells after irradiation [31, 32]. Single cell suspensions $(5-10 \mu 1$, $1-1.5 \times 10^{6}$ cells $/ \mathrm{ml}$ ) were mixed with $60-100 \mu 10.5 \%$ low melting point agarose gel (SeaPlaque ${ }^{\mathrm{TM}}$ Agarose, FMC BioProducts, Belgium) and mounted in circles on scratched microscopic slides (76x26x1.1 mm, 201307, RS France, Laboandco Europe, France)(in triplicate). The slides were incubated for 2 minutes at $4^{\circ} \mathrm{C}$ for gelling and thereafter placed in cold freshly made lysis buffer $\mathrm{pH} 10$ containing 2.5 M NaCl (106404, Merck, Solna, Sweden), $100 \mathrm{mM}$ EDTA (UltraPure ${ }^{\mathrm{TM}}, 15576-028$, invitrogen, UK), $10 \mathrm{mM}$ Tris (UltraPure, 819623, ICN Biomedicals, Ohio, USA), and 1\% Triton X-100 (136597, Fisher Scientific, USA) for a minimum of $18 \mathrm{~h}$ at $4{ }^{\circ} \mathrm{C}$.

The slides were incubated in electrophoresis buffer $\mathrm{pH}>13(300 \mathrm{mM} \mathrm{NaOH}$ (EKA Nobel), 1 mM EDTA (UltraPure $^{\mathrm{TM}}$, 15576-028, Invitrogen, UK)) 20 minutes, at $4^{\circ} \mathrm{C}$, and thereafter placed in electric field $(4 \mathrm{~V}, 7 \mathrm{~mA}$, Power Supply Amersham Pharmacia Biotech, Uppsala, Sweden) using an electrophoresis chamber (Sub-Cell GT Mini, 3866, BioRad, Italy). Electrophoresis was run for $20 \mathrm{~min}$ at $4^{\circ} \mathrm{C}$. Neutralization was done using drops of neutralization buffer $\mathrm{pH} 7.5$ (0.4 M Tris-HCl, Kebo Lab, Fischer Scientific, USA) three times with 5 minutes interval at $4^{\circ} \mathrm{C}$. The slides were incubated in $95 \%$ ethanol (0306046346, Kemetyl AB, Haninge, Sweden) for 5 minutes at $4^{\circ} \mathrm{C}$, dried in air and stored at room temperature in darkness until stained and analyzed.

For analysis, $100 \mu \mathrm{l}$ SyberGold staining solution ( 1 $\mu$ l SYBER Gold stain 10000x concentrate in DMSO, excitation wavelength $496 \mathrm{~nm}$, max emission wavelength 522 nm, 417851, Invitrogen, Oregon, USA) was diluted into $30 \mathrm{ml}$ TE Buffer (10 mM Tris-HCL from Kebo Lab, Fischer Scientific, USA, and 1 mM EDTA, pH7.5-8.0). In each experiment, a minimum of 150 cells were examined for each radiation dose and 3 independent assays for each cell type. Image analysis was performed by ZEN 2.3 software (Bergman Labora Nikon Eclipse E600, 6 filters, Nikon Digital Sight DS-US camera) [91, 92]. For the evaluation of DNA damage, nucleus intensity, tail intensity and tail length were measured (NIS Elements BR, 4.20.01 64-bit, Nikon). The percentage of tail DNA and tail moment were calculated as the following equations [93]:

Tail \% DNA $(\mathrm{TD})=100 \times$ tail intensity $/$ (nucleus intensity + tail intensity)

Tail moment $=$ tail length $\times$ tail $\%$ DNA

Four experimental time points were evaluated to characterize cellular radiation effects: baseline DNA damage in cells that had not been irradiated 0 Gy $0 \mathrm{~h}$ (TD0), and induced DNA damage detected immediately (TDt0), at $24 \mathrm{~h}$ (TDt1) and $48 \mathrm{~h}$ (TDt2) after irradiation. Residual DNA damage (RDD) at $24 \mathrm{~h}$ and $48 \mathrm{~h}$ after radiation was calculated according to the following equation:

$\%$ Residual DNA damage $(\mathrm{RDD} \mathrm{t} 1 ; \mathrm{t} 2)=[(\mathrm{TD} \mathrm{t} 1 ; \mathrm{t} 2$ - TDt0)/ (TDt0 - TD0)] $\times 100$

\section{Clonogenic assay}

After radiation procedure and storage at $4{ }^{\circ} \mathrm{C}$, the cells were trypsinated and resuspended in complemented RPMI medium. Cell counts were determined from two aliquots (TC10 $10^{\mathrm{TM}}$ Automated Cell Counter, Bio-Rad Laboratories AB, Solna, Sweden) and mean was used to transfer 10000 cells into $1.5 \mathrm{ml}$ Eppendorf tubes (E161680L, Eppendorf AG, Hamburg, Germany) and volume adjusted to $1 \mathrm{ml}$ with complemented RPMI medium. Triplicates for each dose were made according to: $10 \mu \mathrm{l}$ cell suspension (corresponding to 100 cells) was transferred to respectively three $60 \mathrm{~mm}$ petri dishes (150288, Nunc ${ }^{\mathrm{TM}}$, Thermo Fischer Scientific, Roskilde, Denmark); $20 \mu \mathrm{l}$ (corresponding to 200 cells) was transferred to respectively three $60 \mathrm{~mm}$ petri dishes. Dishes were incubated at with $4 \mathrm{ml}$ complemented RPMI medium at $37^{\circ} \mathrm{C}$ in humidified air $5 \% \mathrm{CO}_{2}$ atmosphere, for six days. Dishes were washed with Phosphate Buffer Saline (PBS, 09-2051-100, Medicago, Uppsala, Sweden) and incubated for 30 minutes with $6 \%$ glutaraldehyde (Fisher Scientific GTF), 0.5\% Crystal Violet (Serva Electrophoresis GmbH, Heidelberg, Germany) fixation/ staining solution. The dishes were washed with water and allowed to dry at room temperature and in darkness. Colonies ( $>50$ cells/colony) were counted using a visible light source (Olympus CH-2, Japan). Plating efficiency (PE) was defined as the proportion of colonies developed from the seeded cells and calculated according to the equation: $\mathrm{PE}=$ number of colonies/number of seeded cells. The survival fraction (SF) was calculated as follows: 
$\mathrm{SF}=$ number of colonies formed after irradiation/(number of seeded cells $\times$ PE/100) $[94,95]$.

\section{Definitions and statistical analysis}

Statistical analyses were performed using SPSS statistics software, version 23 (IBM Corporation, USA). Since the results of clonogenic and comet assays were not normally distributed, comparison among cell types, irradiation doses ( 0 Gy, 2.5 Gy and 5 Gy) and recovery time ( $0 \mathrm{~h}, 24 \mathrm{~h}$ and $48 \mathrm{~h})$ was carried out by one-way analysis of variance (ANOVA). Heterogeneity of DNA damage was evaluated by variance of DNA damage in tail moment determined for each radiation dose. Nonparametric Mann-Whitney $U$-test was used to test the statistical significance of differences between means of survival fraction, mean variance, plating efficiency, percentage tail DNA, tail moment and residual DNA damage in relation cell types, irradiation doses and recovery time. $P$ value $<5 \%$ was considered as statistically significant.

\section{CONCLUSIONS}

Hybrid cells that arise after fusion between M2macrophages and cancer cells acquire decreased radiation sensitivity, show higher DNA-repair capacity, and survive radiation better compared with their maternal cancer cells. To our knowledge, this is the first in vitro model showing that cell fusion may contribute to the development of subpopulations of radioresistant cancer cells. These findings provide new insights about the biological significance of cell fusion and how it might contribute to clonal evolution and the development of radiation resistance in solid tumors.

\section{Authors' contributions}

- Annelie Lindström: participated in study design, performance of clonogenic survival assay and SCGE and manuscript writing.

- Kristine Midtbö: participated in study design, performance of clonogenic survival assay and SCGE and manuscript writing.

- Stina Garvin: scientific discussion, proofreading and language editing.

- Lars-Gunnar Arnesson: scientific discussion and proofreading.

- Ivan Shabo: participated in study design, statistical analysis and evaluation and manuscript writing.

\section{ACKNOWLEDGMENTS}

The authors want to thank Peter Larsson, Dimitrios Kalafatides, Frida Dohlmar, and Håkan Pettersson at the Department of Radiation Physics, Linköping University and the County Council of Östergötland for making the irradiation procedures possible.

\section{CONFLICTS OF INTEREST}

The authors declare that they have no conflicts of interests.

\section{FUNDING}

This project was supported by grants from the National Organization of Breast Cancer Associations (Sweden), Swedish Cancer Society (Sweden) and County Council of Östergötland (Sweden).

\section{REFERENCES}

1. Pawelek JM, Chakraborty AK. Fusion of tumour cells with bone marrow-derived cells: a unifying explanation for metastasis. Nature reviews Cancer. 2008; 8:377-386.

2. Pawelek J, Chakraborty A, Lazova R, Yilmaz Y, Cooper D, Brash D, Handerson T. Co-opting macrophage traits in cancer progression: a consequence of tumor cell fusion? Contributions to microbiology. 2006; 13:138-155.

3. Shabo I, Stal O, Olsson H, Dore S, Svanvik J. Breast cancer expression of CD163, a macrophage scavenger receptor, is related to early distant recurrence and reduced patient survival. International journal of cancer. 2008; 123:780786.

4. Shabo I, Olsson H, Sun XF, Svanvik J. Expression of the macrophage antigen CD163 in rectal cancer cells is associated with early local recurrence and reduced survival time. International journal of cancer. 2009; 125:1826-1831.

5. Maniecki MB, Etzerodt A, Ulhoi BP, Steiniche T, Borre M, Dyrskjot L, Orntoft TF, Moestrup SK, Moller HJ. Tumorpromoting macrophages induce the expression of the macrophagespecific receptor CD163 in malignant cells. International journal of cancer. 2012; 131:2320-2331.

6. Silk AD, Gast CE, Davies PS, Fakhari FD, Vanderbeek GE, Mori M, Wong MH. Fusion between hematopoietic and epithelial cells in adult human intestine. PLoS One. 2013; 8:e55572.

7. Shabo I, Midtbo K, Andersson H, Akerlund E, Olsson H, Wegman P, Gunnarsson C, Lindstrom A. Macrophage traits in cancer cells are induced by macrophage-cancer cell fusion and cannot be explained by cellular interaction. BMC cancer. 2015; 15:922.

8. Powell AE, Anderson EC, Davies PS, Silk AD, Pelz C, Impey S, Wong MH. Fusion between Intestinal epithelial cells and macrophages in a cancer context results in nuclear reprogramming. Cancer Res. 2011; 71:1497-1505.

9. Nygren JM, Liuba K, Breitbach M, Stott S, Thoren L, Roell W, Geisen C, Sasse P, Kirik D, Bjorklund A, Nerlov C, Fleischmann BK, Jovinge S, et al. Myeloid and 
lymphoid contribution to non-haematopoietic lineages through irradiation-induced heterotypic cell fusion. Nat Cell Biol. 2008; 10:584-592.

10. Johansson CB, Youssef S, Koleckar K, Holbrook C, Doyonnas R, Corbel SY, Steinman L, Rossi FM, Blau HM. Extensive fusion of haematopoietic cells with Purkinje neurons in response to chronic inflammation. Nat Cell Biol. 2008; 10:575-583.

11. Powell AD, Marrion NV. Resolution of fusion pore formation in a cell-attached patch. Journal of neuroscience methods. 2007; 162:272-281.

12. Maier P, Hartmann L, Wenz F, Herskind C. Cellular Pathways in Response to Ionizing Radiation and Their Targetability for Tumor Radiosensitization. International journal of molecular sciences. 2016; 17.

13. Santivasi WL, Xia F. Ionizing radiation-induced DNA damage, response, and repair. Antioxidants \& redox signaling. 2014; 21:251-259.

14. Liptak JM. The principals of surgical oncology: surgery and multimodality therapy. Compendium. 2009; 31:E1-14; quiz E14.

15. Ferlay J, Steliarova-Foucher E, Lortet-Tieulent J, Rosso S, Coebergh JW, Comber H, Forman D, Bray F. Cancer incidence and mortality patterns in Europe: estimates for 40 countries in 2012. European journal of cancer. 2013; 49:1374-1403.

16. Clarke M, Collins R, Darby S, Davies C, Elphinstone P, Evans V, Godwin J, Gray R, Hicks C, James S, MacKinnon E, McGale P, McHugh T, et al. Effects of radiotherapy and of differences in the extent of surgery for early breast cancer on local recurrence and 15-year survival: an overview of the randomised trials. Lancet. 2005; 366:2087-2106.

17. Veronesi U, Cascinelli N, Mariani L, Greco M, Saccozzi R, Luini A, Aguilar M, Marubini E. Twenty-year follow-up of a randomized study comparing breast-conserving surgery with radical mastectomy for early breast cancer. N Engl J Med. 2002; 347:1227-1232.

18. Kurtz JM, Spitalier JM, Amalric R, Brandone H, Ayme Y, Jacquemier J, Hans D, Bressac C. The prognostic significance of late local recurrence after breast-conserving therapy. International journal of radiation oncology, biology, physics. 1990; 18:87-93.

19. van der Leij F, Elkhuizen PH, Bartelink H, van de Vijver MJ. Predictive factors for local recurrence in breast cancer. Seminars in radiation oncology. 2012; 22:100-107.

20. Whelan T, Clark R, Roberts R, Levine M, Foster G. Ipsilateral breast tumor recurrence postlumpectomy is predictive of subsequent mortality: results from a randomized trial. Investigators of the Ontario Clinical Oncology Group. International journal of radiation oncology, biology, physics. 1994; 30:11-16.

21. Gonzalez-Angulo AM, Morales-Vasquez F, Hortobagyi GN. Overview of resistance to systemic therapy in patients with breast cancer. Advances in experimental medicine and biology. 2007; 608:1-22.
22. Vrieling C, Collette L, Fourquet A, Hoogenraad WJ, Horiot JC, Jager JJ, Bing Oei S, Peterse HL, Pierart M, Poortmans PM, Struikmans H, Van den Bogaert W, Bartelink H, et al. Can patient-, treatment- and pathologyrelated characteristics explain the high local recurrence rate following breast-conserving therapy in young patients? European journal of cancer. 2003; 39:932-944.

23. Burrell RA, McGranahan N, Bartek J, Swanton C. The causes and consequences of genetic heterogeneity in cancer evolution. Nature. 2013; 501:338-345.

24. Cooke SL, Temple J, Macarthur S, Zahra MA, Tan LT, Crawford RA, Ng CK, Jimenez-Linan M, Sala E, Brenton JD. Intra-tumour genetic heterogeneity and poor chemoradiotherapy response in cervical cancer. Br J Cancer. 2011; 104:361-368.

25. Fidler IJ, Hart IR. Biological diversity in metastatic neoplasms: origins and implications. Science. 1982; 217:998-1003.

26. Rappa G, Mercapide J, Lorico A. Spontaneous formation of tumorigenic hybrids between breast cancer and multipotent stromal cells is a source of tumor heterogeneity. Am J Pathol. 2012; 180:2504-2515.

27. Nagler C, Hardt C, Zanker KS, Dittmar T. Co-cultivation of murine BMDCs with 67NR mouse mammary carcinoma cells give rise to highly drug resistant cells. Cancer Cell Int. 2011; 11:13.

28. Nagler C, Zanker KS, Dittmar T. Cell Fusion, Drug Resistance and Recurrence CSCs. Advances in experimental medicine and biology. 2011; 714:173-182.

29. Yagi M, Hasegawa J, Nagoshi N, Iizuka S, Kaneko S, Fukuda K, Takemitsu M, Shioda M, Machida M. Does the intraoperative tranexamic acid decrease operative blood loss during posterior spinal fusion for treatment of adolescent idiopathic scoliosis? Spine. 2012; 37:E1336-1342.

30. Carloni V, Mazzocca A, Mello T, Galli A, Capaccioli S. Cell fusion promotes chemoresistance in metastatic colon carcinoma. Oncogene. 2013; 32:2649-2660.

31. Malyapa RS, Bi C, Ahern EW, Roti Roti JL. Detection of DNA damage by the alkaline comet assay after exposure to low-dose gamma radiation. Radiation research. 1998; 149:396-400.

32. Collins AR, Oscoz AA, Brunborg G, Gaivao I, Giovannelli L, Kruszewski M, Smith CC, Stetina R. The comet assay: topical issues. Mutagenesis. 2008; 23:143-151.

33. Olive PL. DNA damage and repair in individual cells: applications of the comet assay in radiobiology. International journal of radiation biology. 1999; 75:395-405.

34. Pietrantonio F, Vernieri C, Siravegna G, Mennitto A, Berenato R, Perrone F, Gloghini A, Tamborini E, Lonardi S, Morano F, Picciani B, Busico A, Volpi CC, et al. Heterogeneity of acquired resistance to anti-EGFR monoclonal antibodies in patients with metastatic colorectal cancer. Clinical cancer research. 2016; 23:2414-2422.

35. Weiskirchen R. Intratumor heterogeneity, variability and plasticity: questioning the current concepts in classification 
and treatment of hepatocellular carcinoma. Hepatobiliary Surg Nutr. 2016; 5:183-187.

36. Gerashchenko TS, Denisov EV, Litviakov NV, Zavyalova MV, Vtorushin SV, Tsyganov MM, Perelmuter VM, Cherdyntseva NV. Intratumor heterogeneity: nature and biological significance. Biochemistry (Mosc). 2013; 78:1201-1215.

37. Yang JY, Ha SA, Yang YS, Kim JW. p-Glycoprotein ABCB5 and YB-1 expression plays a role in increased heterogeneity of breast cancer cells: correlations with cell fusion and doxorubicin resistance. BMC cancer. 2010; 10:388.

38. Ozel C, Seidel J, Meyer-Staeckling S, Brandt BH, Niggemann B, Zanker KS, Dittmar T. Hybrid cells derived from breast epithelial cell/breast cancer cell fusion events show a differential RAF-AKT crosstalk. Cell communication and signaling. 2012; 10:10.

39. Wang R, Chen S, Li C, Ng KT, Kong CW, Cheng J, Cheng SH, Li RA, Lo CM, Man K, Sun D. Fusion with stem cell makes the hepatocellular carcinoma cells similar to liver tumor-initiating cells. BMC cancer. 2016; 16:56.

40. Wakeling WF, Greetham J, Bennett DC. Efficient spontaneous fusion between some co-cultured cells, especially murine melanoma cells. Cell biology international. 1994; 18:207-210.

41. Busund LT, Killie MK, Bartnes K, Seljelid R. Spontaneously formed tumorigenic hybrids of Meth A sarcoma cells and macrophages in vivo. International journal of cancer. 2003; 106:153-159.

42. Goodin JL, Powell BS, Enama JT, Raab RW, McKown RL, Coffman GL, Andrews GP. Purification and characterization of a recombinant Yersinia pestis V-F1 "Reversed" fusion protein for use as a new subunit vaccine against plague. Protein Expr Purif. 2011; 76:136-144.

43. Davies PS, Powell AE, Swain JR, Wong MH. Inflammation and proliferation act together to mediate intestinal cell fusion. PLoS One. 2009; 4:e6530.

44. Zhivotovsky B, Kroemer G. Apoptosis and genomic instability. Nature reviews Molecular cell biology. 2004; 5:752-762.

45. Nehs MA, Lin CI, Kozono DE, Whang EE, Cho NL, Zhu K, Moalem J, Moore FD Jr, Ruan DT. Necroptosis is a novel mechanism of radiation-induced cell death in anaplastic thyroid and adrenocortical cancers. Surgery. 2011; 150:1032-1039.

46. Gewirtz DA. Cytoprotective and nonprotective autophagy in cancer therapy. Autophagy. 2013; 9:1263-1265.

47. Tubiana M. Repopulation in human tumors. A biological background for fractionation in radiotherapy. Acta oncologica. 1988; 27:83-88.

48. Ishibashi N, Maebayashi T, Aizawa T, Sakaguchi M, Nishimaki H, Masuda S. Correlation between the Ki-67 proliferation index and response to radiation therapy in small cell lung cancer. Radiat Oncol. 2017; 12:16.

49. Freudlsperger C, Freier K, Hoffmann J, Engel M. Ki-67 expression predicts radiosensitivity in oral squamous cell carcinoma. Int J Oral Maxillofac Surg. 2012; 41:965-969.
50. Wang XQ, Ellem KA. Heterogeneity in the HeLa cell cycle response to UVC analyzed by the BrdUrd two-parameter method. Experimental cell research. 1994; 212:176-189.

51. Olive PL, Wlodek D, Banath JP. DNA double-strand breaks measured in individual cells subjected to gel electrophoresis. Cancer Res. 1991; 51:4671-4676.

52. Iliakis GE, Okayasu R. Radiosensitivity throughout the cell cycle and repair of potentially lethal damage and DNA doublestrand breaks in an X-ray-sensitive CHO mutant. International journal of radiation biology. 1990; 57:1195-1211.

53. Till JE. Radiation effects on the division cycle of mammalian cells in vitro. Annals of the New York Academy of Sciences. 1961; 95:911-919.

54. Weihua Z, Lin Q, Ramoth AJ, Fan D, Fidler IJ. Formation of solid tumors by a single multinucleated cancer cell. Cancer. 2011; 117:4092-4099.

55. Kaur E, Rajendra J, Jadhav S, Shridhar E, Goda JS, Moiyadi A, Dutt S. Radiation-induced homotypic cell fusions of innately resistant glioblastoma cells mediate their sustained survival and recurrence. Carcinogenesis. 2015; 36:685-695.

56. Gal H, Krizhanovsky V. Cell fusion induced senescence. Aging (Albany NY). 2014; 6:353-354. doi: 10.18632/ aging. 100670 .

57. Busund LT, Killie MK, Bartnes K, Seljelid R. Spontaneously formed tumorigenic hybrids of Meth A sarcoma and macrophages grow faster and are better vascularized than the parental tumor. International journal of cancer. 2002; 100:407-413.

58. Xu MH, Gao X, Luo D, Zhou XD, Xiong W, Liu GX. EMT and acquisition of stem cell-like properties are involved in spontaneous formation of tumorigenic hybrids between lung cancer and bone marrow-derived mesenchymal stem cells. PLoS One. 2014; 9:e87893.

59. Heijink AM, Krajewska M, van Vugt MA. The DNA damage response during mitosis. Mutation research. 2013; 750:45-55.

60. Chakradeo S, Elmore LW, Gewirtz DA. Is Senescence Reversible? Current drug targets. 2016; 17:460-466.

61. Huang Q, Li F, Liu X, Li W, Shi W, Liu FF, O'Sullivan B, He Z, Peng Y, Tan AC, Zhou L, Shen J, Han G, et al. Caspase 3-mediated stimulation of tumor cell repopulation during cancer radiotherapy. Nature medicine. 2011; 17:860-866.

62. Spitz DR, Azzam EI, Li JJ, Gius D. Metabolic oxidation/ reduction reactions and cellular responses to ionizing radiation: a unifying concept in stress response biology. Cancer Metastasis Rev. 2004; 23:311-322.

63. Skvortsov S, Debbage P, Lukas P, Skvortsova I. Crosstalk between DNA repair and cancer stem cell (CSC) associated intracellular pathways. Seminars in cancer biology. 2015; $31: 36-42$.

64. Skvortsova I, Skvortsov S, Stasyk T, Raju U, Popper BA, Schiestl B, von Guggenberg E, Neher A, Bonn GK, Huber LA, Lukas P. Intracellular signaling pathways regulating radioresistance of human prostate carcinoma cells. Proteomics. 2008; 8:4521-4533. 
65. Lagadec C, Vlashi E, Della Donna L, Dekmezian C, Pajonk F. Radiation-induced reprogramming of breast cancer cells. Stem Cells. 2012; 30:833-844.

66. Kelley MR, Georgiadis MM, Fishel ML. APE1/Ref-1 role in redox signaling: translational applications of targeting the redox function of the DNA repair/redox protein APE1/ Ref-1. Curr Mol Pharmacol. 2012; 5:36-53.

67. Fishel ML, Jiang Y, Rajeshkumar NV, Scandura G, Sinn AL, He Y, Shen C, Jones DR, Pollok KE, Ivan M, Maitra A, Kelley MR. Impact of APE1/Ref-1 redox inhibition on pancreatic tumor growth. Mol Cancer Ther. 2011; 10:1698-1708.

68. Diehn M, Cho RW, Lobo NA, Kalisky T, Dorie MJ, Kulp AN, Qian D, Lam JS, Ailles LE, Wong M, Joshua B, Kaplan MJ, Wapnir I, et al. Association of reactive oxygen species levels and radioresistance in cancer stem cells. Nature. 2009; 458:780-783.

69. Jackson SP, Bartek J. The DNA-damage response in human biology and disease. Nature. 2009; 461:1071-1078.

70. Chistiakov DA, Voronova NV, Chistiakov PA. Genetic variations in DNA repair genes, radiosensitivity to cancer and susceptibility to acute tissue reactions in radiotherapytreated cancer patients. Acta oncologica. 2008; 47:809-824.

71. Wang R, Sun X, Wang CY, Hu P, Chu CY, Liu S, Zhau HE, Chung LW. Spontaneous cancer-stromal cell fusion as a mechanism of prostate cancer androgen-independent progression. PLoS One. 2012; 7:e42653.

72. Chistiakov DA, Potapov VA, Khodirev DC, Shamkhalova MS, Shestakova MV, Nosikov VV. Genetic variations in the pancreatic ATP-sensitive potassium channel, beta-cell dysfunction, and susceptibility to type 2 diabetes. Acta diabetologica. 2009; 46:43-49.

73. Parshad R, Price FM, Bohr VA, Cowans KH, Zujewski JA, Sanford KK. Deficient DNA repair capacity, a predisposing factor in breast cancer. Br J Cancer. 1996; 74:1-5.

74. Dittmar T, Nagler C, Schwitalla S, Reith G, Niggemann B, Zanker KS. Recurrence cancer stem cells - made by cell fusion? Medical hypotheses. 2009; 73:542-547.

75. Olive PL. The role of DNA single- and double-strand breaks in cell killing by ionizing radiation. Radiation research. 1998; 150:S42-51.

76. Kreso A, O'Brien CA, van Galen P, Gan OI, Notta F, Brown AM, Ng K, Ma J, Wienholds E, Dunant C, Pollett A, Gallinger S, McPherson J, et al. Variable clonal repopulation dynamics influence chemotherapy response in colorectal cancer. Science. 2013; 339:543-548.

77. Marusyk A, Tabassum DP, Altrock PM, Almendro V, Michor F, Polyak K. Non-cell-autonomous driving of tumour growth supports sub-clonal heterogeneity. Nature. 2014; 514:54-58.

78. Marusyk A, Polyak K. Cancer. Cancer cell phenotypes, in fifty shades of grey. Science. 2013; 339:528-529.

79. Almendro V, Marusyk A, Polyak K. Cellular heterogeneity and molecular evolution in cancer. Annual review of pathology. 2013; 8:277-302.
80. De Baetselier P, Gorelik E, Eshhar Z, Ron Y, Katzav S, Feldman M, Segal S. Metastatic properties conferred on nonmetastatic tumors by hybridization of spleen B-lymphocytes with plasmacytoma cells. J Natl Cancer Inst. 1981; 67:1079-1087.

81. Flasza M, Shering AF, Smith K, Andrews PW, Talley P, Johnson PA. Reprogramming in inter-species embryonal carcinoma-somatic cell hybrids induces expression of pluripotency and differentiation markers. Cloning and stem cells. 2003; 5:339-354.

82. Chen EH, Olson EN. Unveiling the mechanisms of cell-cell fusion. Science. 2005; 308:369-373.

83. Duelli D, Lazebnik Y. Cell-to-cell fusion as a link between viruses and cancer. Nature reviews Cancer. 2007; 7:968-976.

84. Rizvi AZ, Swain JR, Davies PS, Bailey AS, Decker AD, Willenbring H, Grompe M, Fleming WH, Wong MH. Bone marrow-derived cells fuse with normal and transformed intestinal stem cells. Proc Natl Acad Sci USA. 2006; 103:6321-6325.

85. Chakraborty AK, Pawelek J, Ikeda Y, Miyoshi E, Kolesnikova N, Funasaka Y, Ichihashi M, Taniguchi N. Fusion hybrids with macrophage and melanoma cells up-regulate $\mathrm{N}$-acetylglucosaminyltransferase V, beta1 -6 branching, and metastasis. Cell Growth Differ. 2001; 12:623-630.

86. Chakraborty A, Lazova R, Davies S, Backvall H, Ponten F, Brash D, Pawelek J. Donor DNA in a renal cell carcinoma metastasis from a bone marrow transplant recipient. Bone Marrow Transplant. 2004; 34:183-186.

87. Yilmaz Y, Lazova R, Qumsiyeh M, Cooper D, Pawelek J. Donor Y chromosome in renal carcinoma cells of a female BMT recipient: visualization of putative BMT-tumor hybrids by FISH. Bone Marrow Transplant. 2005; 35:1021-1024.

88. Lazova R, Laberge GS, Duvall E, Spoelstra N, Klump V, Sznol M, Cooper D, Spritz RA, Chang JT, Pawelek JM. A Melanoma Brain Metastasis with a Donor-Patient Hybrid Genome following Bone Marrow Transplantation: First Evidence for Fusion in Human Cancer. PLoS One. 2013; 8:e66731.

89. LaBerge GS, Duvall E, Grasmick Z, Haedicke K, Pawelek J. A Melanoma Lymph Node Metastasis with a Donor-Patient Hybrid Genome following Bone Marrow Transplantation: A Second Case of Leucocyte-Tumor Cell Hybridization in Cancer Metastasis. PLoS One. 2017; 12:e0168581.

90. Shabo I, Olsson H, Elkarim R, Sun XF, Svanvik J. Macrophage Infiltration in Tumor Stroma is Related to Tumor Cell Expression of CD163 in Colorectal Cancer. Cancer microenvironment. 2014; 7:61-69.

91. Azqueta A, Collins AR. The essential comet assay: a comprehensive guide to measuring DNA damage and repair. Archives of toxicology. 2013; 87:949-968.

92. Collins AR. The comet assay for DNA damage and repair: principles, applications, and limitations. Molecular biotechnology. 2004; 26:249-261.

93. Konca K, Lankoff A, Banasik A, Lisowska H, Kuszewski T, Gozdz S, Koza Z, Wojcik A. A cross-platform public 
domain PC image-analysis program for the comet assay. Mutation research. 2003; 534:15-20.

94. Munshi A, Hobbs M, Meyn RE. Clonogenic cell survival assay. Methods in molecular medicine. 2005; 110:21-28.
95. Franken NA, Rodermond HM, Stap J, Haveman J, van Bree C. Clonogenic assay of cells in vitro. Nature protocols. 2006; 1:2315-2319. 